\title{
Production and Biochemestry-Molecular Analysis of Microbial Community Fermenting Whey as a Potential Probiotic for Use Animals
}

\author{
Eduardo N. Esteban ${ }^{1}$, Mirentxu Indart ${ }^{2}$, Silvia Cerone², G. de Yaniz ${ }^{2}$, Ana G. Inza ${ }^{2}$, Herminia Landi ${ }^{3}$, \\ Silvina Mogni' ${ }^{2}$, Marcela Juliarena ${ }^{1}$, Leticia Igarza ${ }^{2 *}$ \\ ${ }^{1}$ Department of Animal Health, Faculty of Veterinary Science, Universidad Nacional del Centro de la Provincia de Buenos Aires, \\ Tandil, Argentina \\ ${ }^{2}$ Department of Physiology and Pathology, Faculty of Veterinary Medicine, Universidad Nacional del Centro de la Provincia de \\ Buenos Aires, Tandil, Argentina \\ ${ }^{3}$ Department of Animal Production, Faculty of Veterinary Science, Universidad Nacional del Centro de la Provincia de Buenos Aires, \\ Tandil, Argentina \\ Email: *letigar@vet.unicen.edu.ar
}

Received May 29, 2012; revised June 28, 2012; accepted July 10, 2012

\begin{abstract}
The aims of this work were: To achieve a simple and low cost propagation of potential probiotic agents using plain whey as a culture medium, study the diversity of the members of the bacterial community (MC) in plain whey and to evaluate the probiotic capacity of this MC. After a systematic selection of agents according to their growing capacity in whey, the constituted MC was considered as a unit. Biochemical characterization of the lactic acid bacteria were performed using the API system. Molecular characterization of the lactic acid bacteria was realized using AFLP ${ }^{\mathrm{TM}}$ DNA-fingerprinting, partial 16S rDNA sequence analysis and PCR-denaturing gradient gel electrophoresis (PCR-DGGE). The physiological characterization of yeast was determined with the automated microplate method Allev/Biolomics and using yeast characterization system based on standard taxonomic criteria. The identification molecular was realized by PCR-fingerprinting. The resistance of MC to $\mathrm{pH}$ and bile salts were evaluated. The MC was composed of agents from different separated Dominium like Bacteria (Lactobacillum) and Eukaria (yeast). They are multispecies and also multistrain assuring high biodiversity. The MC grew at low pH and different concentrations bile salts.
\end{abstract}

Keywords: Probiotic; Multispecies; Multistrain; Plain Whey

\section{Introduction}

Whey is a cheese industry effluent and a powerful environmental contaminant, in most cheese making regions in Argentina. In recent years, the recovery and marketing of whey components like proteins, minerals and lactose has diminished the quantities of this effluent discarded to the environment [1]. The fermentation of whey by different procedures as an alternative to produce single cell protein, beverages, ethanol and methane has been communicated by various authors [2-4]. In our case the production of a microbial community fermenting whey could be utilized as potential probiotic in animals. A probiotic is a "live microbial feed supplement which beneficially affects the host animal by improving its intestinal microbial balance" [5]. Thus, using a probiotic means an intervention on the intestinal ecosystem. Probiotic bacteria would have antagonistic impact against intestinal in-

"Corresponding author. fectious bacteria just by competitive exclusion [6], modulating the intestinal medium, favoring growth of friendly bacteria or producing natural antibiotics or bacteriocines [7].

The aim of this work was: To conform a microbial community of simple and low cost propagation with potential probiotic agents using plain whey as a culture medium, to analyze the species that constitute the microbial community (MC) by means isolating and identifying strains through the application biochemistry and molecular techniques and to evaluate the probiotic capacity of this MC.

\section{Materials and methods}

Development of the microbial community: Fresh pooled whey from cheese producing companies located in Tandil, Argentina, was collected and transported to destination in food grade stainless steel tanks. Average 
protein concentration was $3.5 \pm 0.5 \mathrm{mg} / \mathrm{ml}$ and $\mathrm{pH} 5.7 \pm$ 0.3. Immediately after arriving, whey was centrifuged up to $2800 \mathrm{xg}$ keeping a continuous flow of $4.167 \mathrm{l} / \mathrm{min}$, at room temperature. Fat free whey was sterilized by micro filtering successively through $1 \mu, 0.5 \mu$ and $0.1 \mu$ pore size Koch membranes and was used for MC development.

We examined whey fermentation capacity of some Caucasian Kefir agents and then added local lactic acid bacteria obtained from pooled whey in local cheese producing plants. Criteria for the addition of new local strains were as follows: The final $\mathrm{pH}$ had to be lower and the biomass (g/l) had to be equal or larger than obtained by Kefir agents. It was considered a satisfactory community fermenting whey which consistently drops $\mathrm{pH}$ down to $3.6 \pm 0.1$ and biomass increases to $6 \pm 0.5 \mathrm{~g} / \mathrm{l}$ after 24 $\mathrm{h}$ culture. Cultures were incubated $24 \mathrm{~h}$ in stationary conditions at $37^{\circ} \mathrm{C}$. Biomass was harvested by centrifugation at $10^{\circ} \mathrm{C}$ and $2800 \mathrm{xg}$ keeping a continuous flow of $4.167 \mathrm{l} / \mathrm{min}$.

Freeze-drying: Compact biomass obtained by MC centrifugation was suspended (1:2) in $10 \%(\mathrm{w} / \mathrm{v})$ reconstituted skim milk and 5\% (w/v) sodium glutamate $(\mathrm{pH}$ was adjusted to 5 with $1 \mathrm{M} \mathrm{NaOH}$ ). Bacterial suspension was freeze-drier. After the freeze-drying cycle has been complete, dried $\mathrm{MC}$ was stored at $4^{\circ} \mathrm{C}$ under vacuum.

Isolation and biochemical characterization of the lactic acid bacteria were carried out by the Centro de referencia de Lactobacillus, Tucumám, Argentina (CERELA).

Lactic acid bacteria isolation: A twenty grams sample of the compact biomass obtained by MC centrifugation were added to $180 \mathrm{ml}$ of saline-2 peptone water $(2 \%$ of $\mathrm{NaCl}, 0.1 \%$ of bacteriological peptone and $1 \%$ of Tween 80) and mixed for 3 min into a sterile stomacher bag (Stomacher Lab-Blender 400, A. J. Seward Lab., London, England)

Serial dilutions were made in $1 \%$ peptone water and plated on MRS [8] agar, MRS pH 5.4, LAPTg agar [9], KF agar and ST medium, all supplemented with cycloheximide $(25 \mu \mathrm{g} / \mathrm{ml})$ to suppress yeast growth. Plates were incubated at $30^{\circ} \mathrm{C}$ and $37^{\circ} \mathrm{C}$ anaerobically for 6 days. Isolated colonies that differed microscopically were randomly selected. The isolates were propagated in MRS broth and purified. Gram positive rods and negative to catalase reaction were selected for further studies as presumptive Lactobacillus species.

Biochemical characterization: Bacteria were first clustered on the basis of cellular morphology, growth at $15^{\circ} \mathrm{C}, 30^{\circ} \mathrm{C}, 37^{\circ} \mathrm{C}$ and $45^{\circ} \mathrm{C}, 0.1 \%$ and $0.3 \%$ methylene blue, nitrate reduction, indol production, ammonia production from arginina, esculin hydrolysis, $\mathrm{CO}_{2}$ production from glucose and gluconate, ability to form diacetyl from citrate. Carbohydrate fermentation tests of selected lactobacilli were performed using the API 50CH system (bio-
Merieux, Marcyl' Etoile France) according to the manufacturer instructions. Tests preparations were incubated at $37^{\circ} \mathrm{C}$ and final readings were made after $48 \mathrm{~h}$. Fermentation profiles were analyzed by APILAB Plus version 4.0 program (bioMerieux, Marcyl’ Etoile France).

Molecular characterization of the lactic acid bacteria: $A_{F L P}{ }^{\mathrm{T}}$ DNA-fingerprinting, partial $16 \mathrm{~S}$ rDNA sequence analysis and PCR-denaturing gradient gel electrophoresis (PCR-DGGE) were carried out by the BCCM/ LMG Bacteria Collection (Ghent University. Belgium). AFLP $^{\mathrm{TM}}$ (The AFLP ${ }^{\mathrm{TM}}$ technology is subject to patents and patent applications and AFLP is a registered trademark, all owned by Keygene N. V., the Netherlands) is a PCR based technique for whole genome DNA fingerprinting via the selective amplification of restriction fragments [10].

Five lyophilized individual specie biochemically characterized and 2 lyophilized samples of the whole MC, obtained 4 months apart, were sent to the BCCM/LMG. The twelve lyophilized cultures were recovered and checked for purity on MRS (Oxoid CM361) after anaerobic incubation at $37^{\circ} \mathrm{C}$ for $72 \mathrm{~h}$. One well isolated colony was picked for further cultivation and subsequent analyses. Elementary bacteriological tests (cell morphology, gram stain, oxidase and catalase reactions) were performed for purity check.

DNA was prepared using the method of Gevers et al. 2001 [11], slightly modified. Purified total DNA was digested by two restriction enzymes ( 4 and 6 base cutter). In this way, only a limited number of fragments with two different ends and of suitable size for efficient PCR were obtained. Small ds DNA molecules (15 - 20 bp) containing one compatible end were ligature to the appropriate "sticky end" of the restriction fragments. Both adaptors are restriction half site-specific and have different sequences. These adaptors serve as binding sites for PCR primers. In the current analyses, the following restriction enzymes and adaptors were used:

Restriction enzyme: EcoR I [hexacutter]

Adaptor: 5'-CTCGTAGACTGCGTACC-3' 3'-CTGA CGCATGGTTAA-5'

Restriction enzyme: Taq I [tetracutter]

Adaptor: 5'-GACGATGAGTCCTGAC-3'

$$
\text { 3'-TACT CAGGACTGGC-5' }
$$

Selective amplification of some of the restriction fragments: PCR primers were specifically hybridized with the adaptor ends of the restriction fragments. Since the primers contain at their 3'-end one or more so-called "selective bases" that extend beyond the restriction site into the fragment, only those restriction fragments that have the appropriate complementary sequence adjacent to the restriction site will be amplified. Following primer combination was used:

E01:5’-GACTGCGTACCAATTCA-3’, T11:5’-GTTT 
CTTATGAGTCCTGACCGAA-3'. PCR products were separated according to their length using an ABI Prism ${ }^{\circledR}$ 3130XL Genetic Analyzer. Fragments that contain an adaptor specific for the restriction half site created by the 6-bp cutter are visualized due to the 5'-end labeling of the corresponding primer with the fluorescent dye FAM.

The resulting electrophoreses patterns were normalized and subjected to a band pattern recognition procedure using the GeneMapper 4.0 software (Applera, USA). A normalized table of peaks, containing fragments of 20 to 600 base pairs, was transferred into the BioNumer$\operatorname{ics}^{\mathrm{TM}} 4.61$ software. For numerical analysis, a data interval was delineated between the 40 and 580 bp bands of the internal size standard. The profiles were compared with the reference profiles of the lactic acid bacteria (including bifidobacteria) as currently available in BCCM database. Clustering of the patterns was done using the Dice coefficient and the Upgma algorithm.

Partial 16S rDNA sequence analysis and phylogenetic study: DNA prepared for the PCR-DGGE analyses was used. 16S rRNA genes were amplified by PCR using the forward primer 16F27 (pA) 5'AGA GTT TGA TCC TGG CTC AG 3' and 6R1522 (pH) 5'AAG GAG GTG ATC CAG CCG CA 3' (hybridizing position referring to E. coli 16S rRNA gene sequence numbering 8-27 and 1541-1522 respectively). PCR amplified 16S rDNAs were purified using the NucleoFast ${ }^{\circledR} 96$ PCR Clean-up Kit (Macherey-Nagel, Düren, Germany). Sequencing reactions were performed using the BigDye ${ }^{\circledR}$ Terminator Cycle Sequencing Kit and purified using the BigDye ${ }^{\circledR}$ XTerminatorT Purification Kit Sequencing was performed using an ABI Prism ${ }^{\circledR}$ 3130XL Genetic Analyzer (Applied Biosystems, Foster City, CA, USA).

The following forward and reverse primers were used to get a partial overlap of sequences, ensuring highly reliable assembled data: 16F358 (Gamma) 5'CTC CTA CGG GAG GCA GCA GT 3', 16R339 (Gamma) 5'ACT GCT GCC TCC CGT AGG AG 3', 16R519 (BKL1) 5' GTA TTA CCG CGG CTG CTG GCA 3' (hybridizing position referring to $\mathrm{E}$. coli $16 \mathrm{~S}$ rRNA gene sequence numbering 339-358, 358-339 and 536-516). Sequence assembly was performed by using the program Autoassembler $^{\mathrm{TM}}$ (Applied Biosystems, Foster City, CA, USA).

A similarity matrix was created using the software package Bio Numerics (Applied Maths, Belgium) by homology calculation with a gap penalty of $0 \%$ and after discarding unknown bases and is based on pairwise alignment using an open gap penalty of $100 \%$ and a unit gap penalty of $0 \%$.

Phylogenetic analysis was performed using the software package Bio Numerics after including the consensus sequence in an alignment of small ribosomal subunit sequences collected from the international nucleotide sequence library EMBL. A resulting tree was constructed using the neighbor-joining method.

PCR-denaturing gradient gel electrophoresis (PCRDGGE): PCR-DGGE analysis was carried out as described in Van Hoorde et al., 2008 [12].

Physiological and molecular characterization of yeast.

Each sample of freezer-died power of MC after addition of an equal amount of peptone water were cultured on dextrose yeast extract peptone agar (DYPA) with $0.02 \%$ of chloramphenicol. The physiological and morphological profiles of the yeast isolates were determined with the automated microplate method Allev/Biolomics (BioAware SA, Hannut, Belgium) [13], and using yeast characterization system based on standard taxonomic criteria $[14,15]$. The identification molecular was realized according to Kutzman and Robnett 1998 [16] and Barnett et al., 2000 [17].

For DNA sequence analyses, the primer pair LR0RLR6 was used to amplify the D1/D2 region of the large subunit (LSU) of the ribosomal gene complex [18]. Successful PCR amplifications resulted in a single band observed on a $0.8 \%(\mathrm{w} / \mathrm{v})$ agarose gel, corresponding to approximately $600 \mathrm{bp}$. PCR products were cleaned using the QIAquick PCR purification kit, following the manufacturer's protocol. Sequencing reactions were performed using a CEQ DTCS Quick Start Kit (Beckman Coulter, Fullerton, California, USA), according to the manufacturer's recommendations, with the primers LROR and LR3. Nucleotide sequences were determined using a CEQ 2000 XL capillary automated sequencer. The sequences were assembled and edited in Sequencher 4.8 (Gene Codes Corp., Ann Arbor, Michigan, USA). After initial BLAST searches for the most similar sequences, alignments were performed to compare type strain sequences with the query sequences. The number of substitutions and potential insertions or deletions (indels) was determined from these pairwise comparisons using BioEdit 7.0.5.3 [19]. The sequences were deposited in the EMBL databank (http://www.ebi.ac.uk/EMBL; Hinxton, UK) with accession numbers DIV/08 $182 \mathrm{~A}, 182 \mathrm{~B}$, $182 \mathrm{C}, 182 \mathrm{D}$.

High-molecular-mass DNA for PCR-fingerprint analyses was extracted using the Invisorb ${ }^{\circledR}$ Spin Plant Mini Kit (Invitek GmbH, Berlin, Germany) as described by Groenewald et al., 2008 [20]. PCR-based fingerprinting with the single primer M13, a ubiquitous microsatellite sequence [21], was applied as described before by Groenewald et al., 2008 [20]. The resulting M13-based PCRfingerprint profiles were compared visually with reference strains.

"In vitro" evaluation of the MC probiotic capacity. An aliquot of MC, was inoculated into acidified MRS broth to $\mathrm{pH} 2.5,3$ and 4 with $\mathrm{HCl}(1 \mathrm{~N})$ and non-acidified (pH 6.8) and incubated for $3 \mathrm{~h}$ at $37^{\circ} \mathrm{C}$. 
After incubation, serial dilutions in peptone water were spread onto MRS agar plates. Plates were incubated anaerobically for $48 \mathrm{~h}$ at $37^{\circ} \mathrm{C}$.

Percentage of resistance to each analyzed $\mathrm{pH}$ was calculated by the equation: \%RpH $=\left[(\mathrm{UFC} / \mathrm{ml})_{\mathrm{MRS} \mathrm{pH} . .} \times\right.$ $100] /(\mathrm{UFC} / \mathrm{ml})_{\text {MRS pH } 6.5}$ [22].

An aliquot of MC was inoculated into acidified MRS broth with $0.03,0.05$ and 0.1 concentrations of bile salt and within bile salts and incubated for $3 \mathrm{~h}$ at $37^{\circ} \mathrm{C}$.

After incubation, serial dilutions in peptone water were spread onto MRS agar plates at $1 \mathrm{~h}$ and $3 \mathrm{~h}$ post incubation. Plates were incubated anaerobically for $48 \mathrm{~h}$ at $37^{\circ} \mathrm{C}$.

Percentage of resistance to each analyzed bile salt concentration was calculated by the equation: $\% \mathrm{RpH}=$ $\left[(\mathrm{UFC} / \mathrm{ml})_{\mathrm{MRS} \mathrm{pH} . . .} \times 100\right] /(\mathrm{UFC} / \mathrm{ml})_{\mathrm{MRS} \mathrm{pH} 6.5}$ [22].

\section{Result}

\subsection{Development}

In optimum anaerobic culture conditions, the biomass production in creased to $6 \pm 0.5 \mathrm{~g} / \mathrm{l}$ and $\mathrm{pH}$ fell to $3.6 \pm$ 0.1 after 24 h culture. Periodic microscopic examination of the MC showed a homogeneous proportion in the quantity of yeast and lactic acid bacteria.

The viability after MC rehydration was $3.2 \times 10^{9}$ lactobacilli plus $1.5 \times 10^{6}$ yeast CFU per gram lyophilized compact biomass.

\subsection{Isolation and Biochemical Characterization of the Lactic Acid Bacteria}

Most of the random isolates from MC (95\%) expressed general characteristics corresponding to lactic acid bacteria (Gram-positive, catalase-negative, non-motile rods).

From each resulting cluster, one to four strains were selected for further analysis so twelve lactobacilli were characterized by fermentation profiles.

Phenotypic characterization of the microbial community indicated the following species and strains: Lactobacillus helveticus (ID11609, ID11610, ID11618), Lactobacillus delbrueckii (ID11611), Lactobacillus paracasei (11614), Lactobacillus fermentum (ID11613, ID11616, ID11619), Lactobacillus sp (ID11612, ID11615, ID11617), and Lactobacillus buchneri (ID11620).

\subsection{Molecular Characterization of Lactic Acid Bacteria}

The results of the identification using AFLP and 16S and PCR-DGGE are given.

Two colony types were isolated from ID11615: Smooth (t1) and rough (t2) colony. The Lactobacillus identificated were: L. helveticus (ID11609, ID11610, ID11611 and ID11612), L. fermentum (ID11613, ID11615 t1, ID11616), L. paracasei ID11614, ID11618), L. casei (ID11617), L. parabuchneri (ID11620) as are shown in the dendograms of the cluster analyses of $\mathrm{AFLP}^{\mathrm{TM}}$ profiles (Figures 1-4).

For the rough colony and for ID11619, no profile could be obtained. Parcial 16S rDNA sequence analysis was carried out. The percentage 16S rDNA sequence similarity was Lactobacillus gasseri DSM 20243 ${ }^{\mathrm{T}}$ (100) and Lactobacillus panis DSM 6035 ${ }^{\mathrm{T}}$ (99.8) respectively.

Similar DGGE results were obtained for both gradients (35\% - 60\% and 35\% - 70\%). The results are shown in Figure 5.

\subsection{Physiological and Molecular Characterization of Yeast}

The results obtained are shown in Table 1.

\section{5. “In Vitro" Evaluation of the MC Probiotic Capacity}

Obtained percentage of resistance $\mathrm{pH}$ and bile salts are shown in Table 2.

\section{Discussion and Conclusions}

The Kefir is a complex probiotic. Its lactobacilli and yeast components were selected over thousands of years towards milk fermentation [23]. In a similar manner, we took from Kefir the most adaptable members to grow in whey. Other lactobacilli and yeast found in our environment, and which improved whey fermentation, were also selected and incorporated to the developing consortium. Based on a consistent fermentation in successive whey baths, determined by $\mathrm{pH}$ modification and sensorial examinations like smell and taste, we considered the constituted community as a unit. This consistent fermentation suggested a symbiotic relationship and adaptation capacity of the MC.

This MC is composed by at least seven lactic acid bacteria and two yeast species, comprising agents from separated dominium like Eukaria and Bacteria. The application of molecular biology tools to better understand the integrated process of this complex consortium would allow us, in the near future, to use specific community members, or specifically tailored consortia of members, to target desired interactions, resulting in health benefits and food production improvement [24,25].

Selected lactic acid bacteria and yeast are multispecies and also multistrain assuring high biodiversity. The advantage of multistrain and multispecies probiotics is that a number of favorable characteristics of individual strains are combined in a single preparation [26]. It has been clearly shown that multispecies preparations have advantages when compared to monostrain probiotics or, to a lesser extent, multistrain probiotics [27]. Well-designed 
multispecies probiotics can benefit from a certain amount of synergism when the effects of different probiotic species are combined $[28,29]$. The activity can also be stimulated through simbiosis among strains in the prepa- ration [30-32]. How probiotics, whether monospecies or multistrain/mulitispecies formulations, actually helping the host to attain such greater protection levels is still poorly understood $[32,33]$.

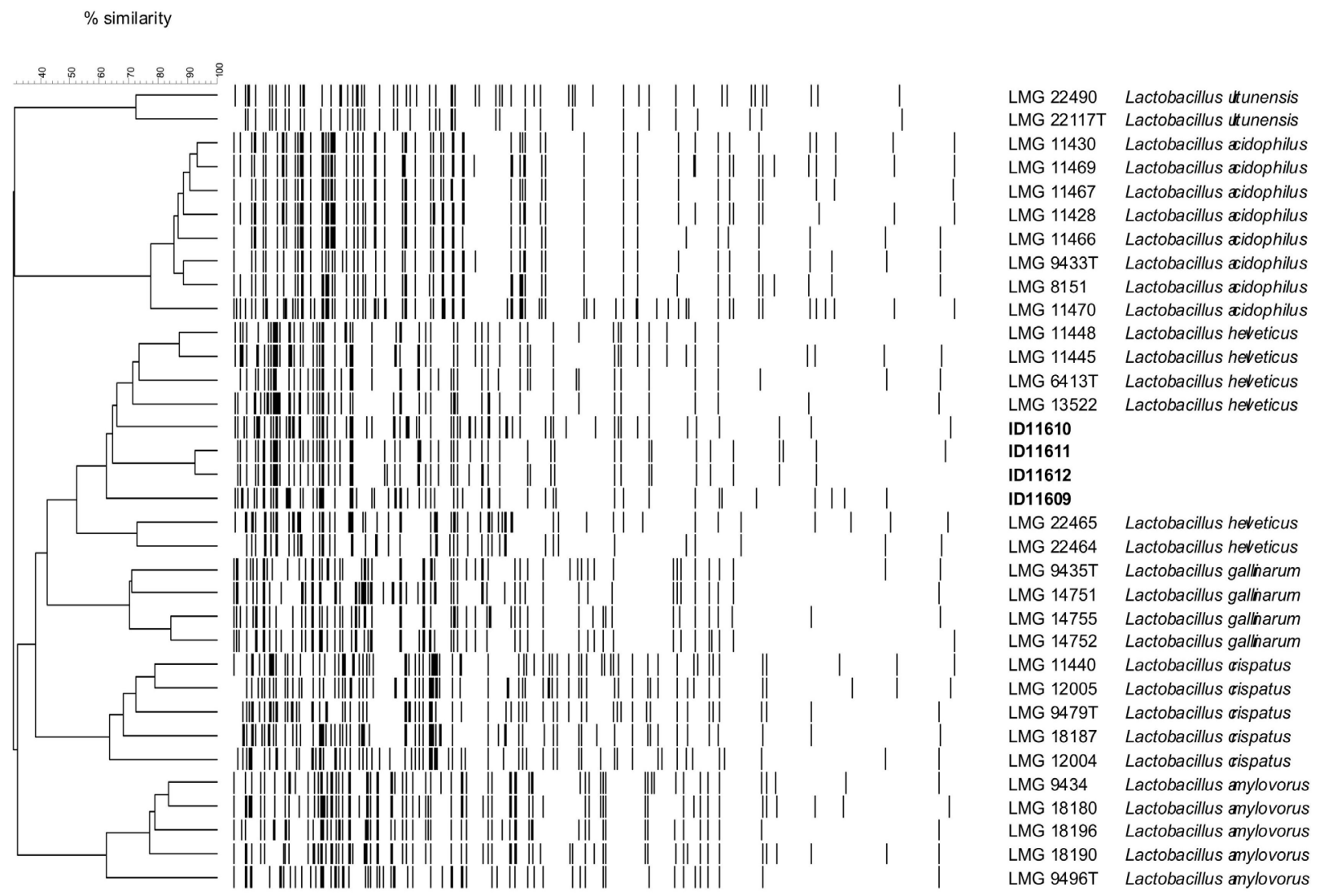

Type strains are indicated with $\mathrm{T}$.

Figure 1. Dendrogram of the cluster analyses of AFLP ${ }^{\mathrm{TM}}$ profiles (ID11609-D11612).

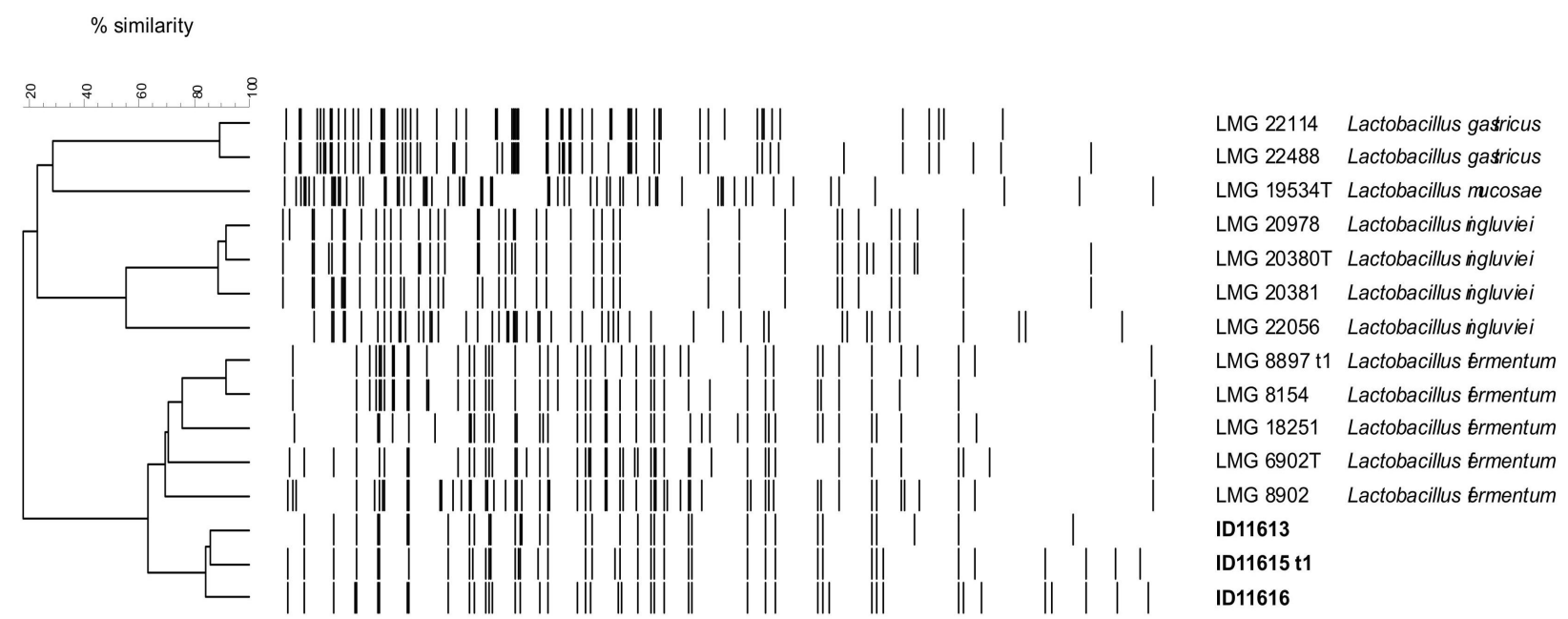

Type strains are indicated with $\mathrm{T}$.

Figure 2. Dendrogram of the cluster analyses of AFLP ${ }^{\mathrm{TM}}$ profiles (ID11613, ID11615 t1 and ID11616). 


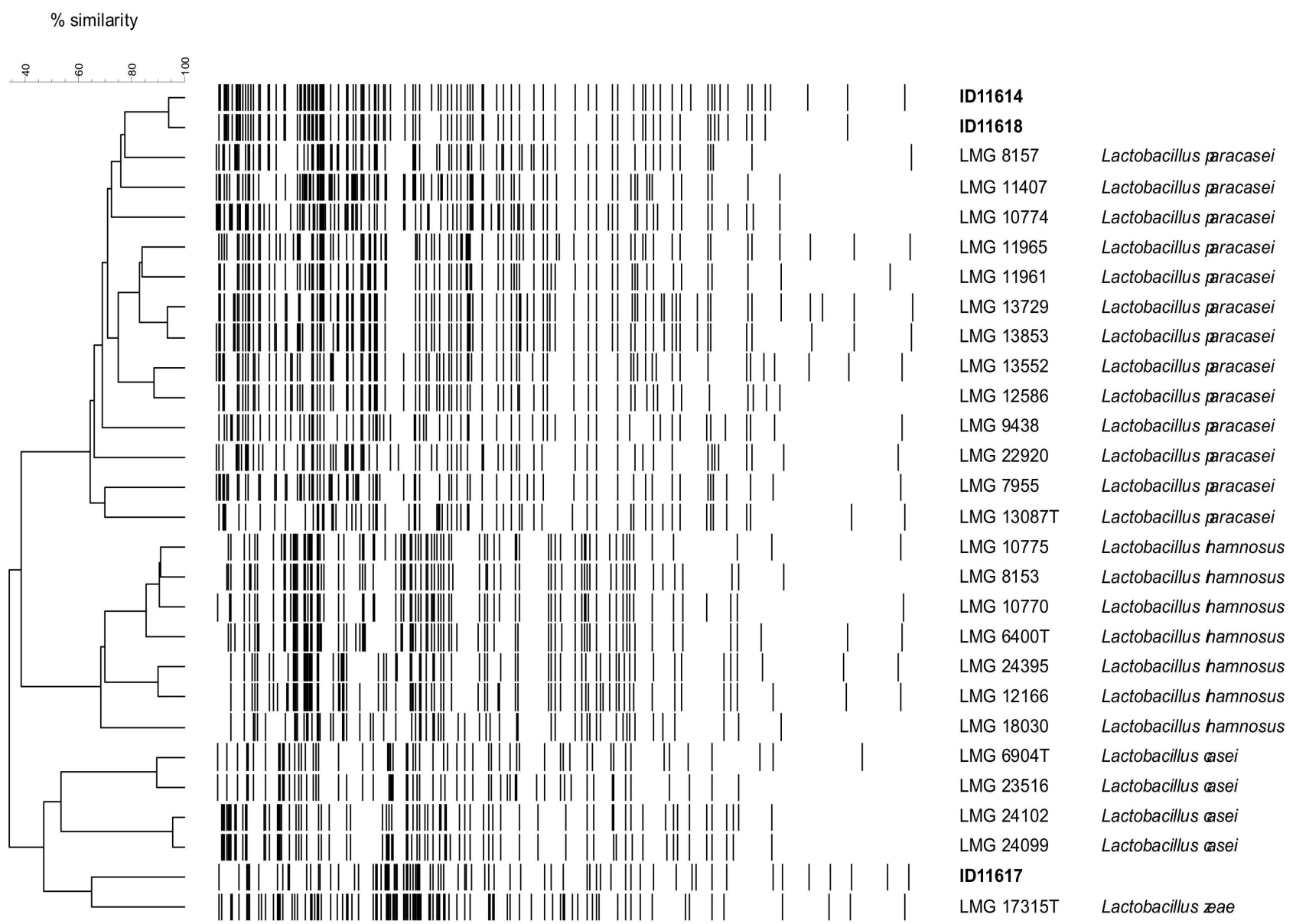

Type strains are indicated with $\mathrm{T}$.

Note: Lactobacilus zeae is a later heterotypic synonym of Lactobacillus casei.

Figure 3. Dendrogram of the cluster analyses of AFLP ${ }^{\mathrm{TM}}$ profiles (ID11614, ID11617 and ID11618).

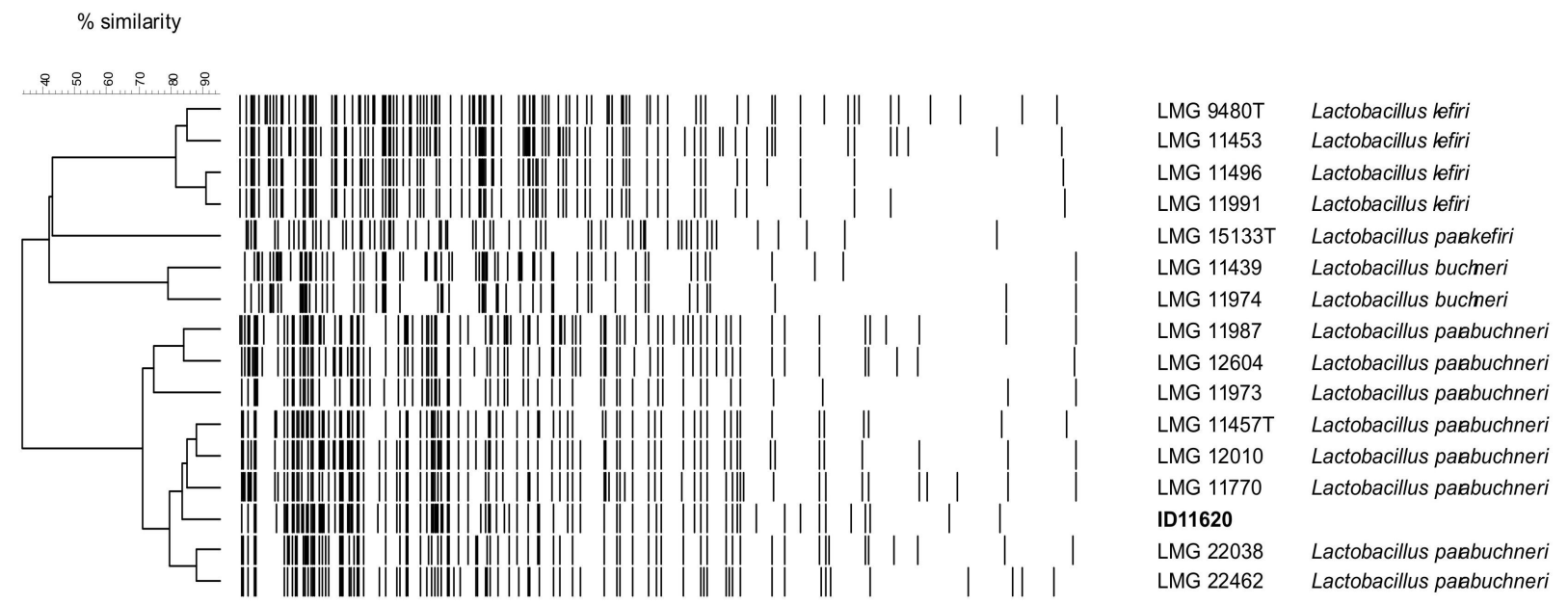

Type strains are indicated with $T$.

Please note that the current 'LAB' database does not contain a profile of the type strain of Lactobacillus buchneri.

Figure 4. Dendrogram of the cluster analyses of AFLP ${ }^{\mathrm{TM}}$ profiles (ID11620). 


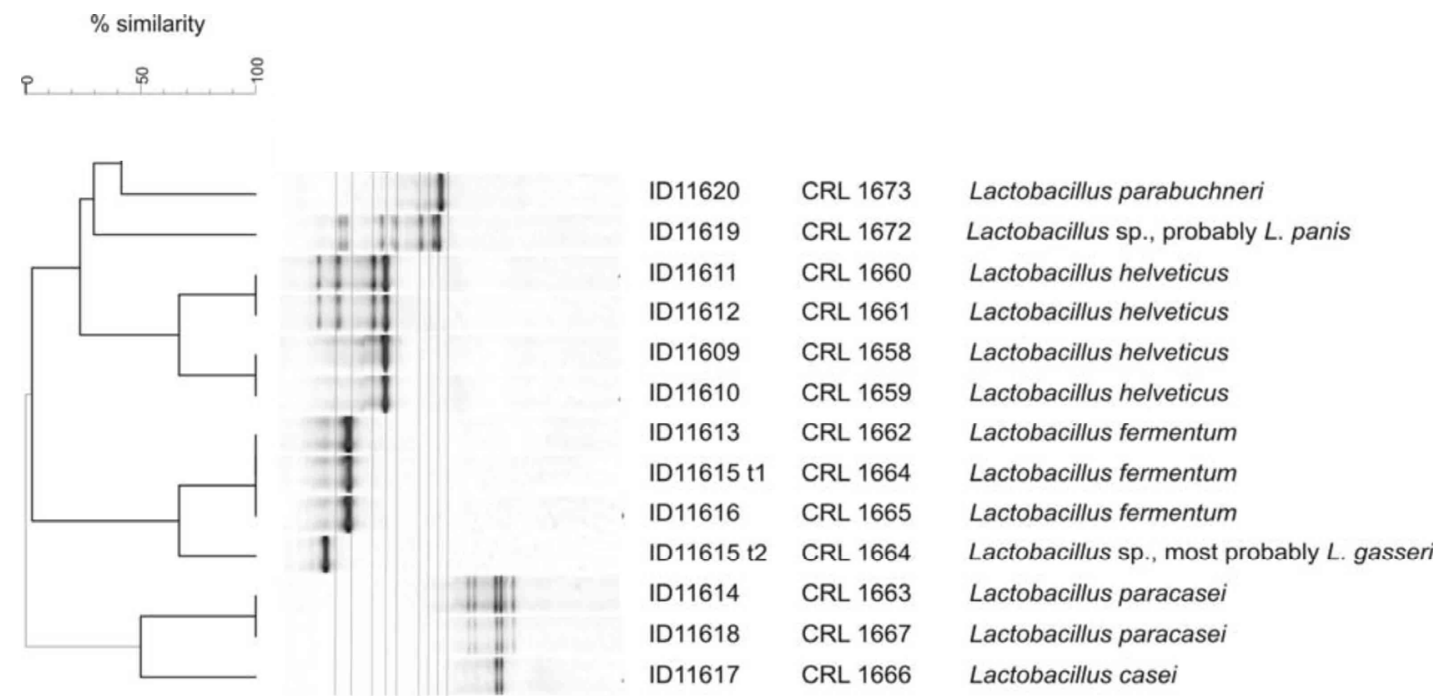

Figure 5. PCR denaturing gradient gel electrophoresis (35\% - 70\%). Computer out prints of the profiles obtained for the 13 samples.

Table 1. Yeast isolates, colony types and the results morphological and physiological characterization and molecular identification.

\begin{tabular}{ccccc}
\hline Reference & $\begin{array}{c}\text { BCCM/MUCL } \\
\text { Collection number }\end{array}$ & Colony type & $\begin{array}{c}\text { Morphology and } \\
\text { physiological characterization }\end{array}$ & $\begin{array}{c}\text { Molecular identification by D1/D2 } \\
\text { large subunit rDNA sequence }\end{array}$ \\
\hline DIV/08-182A & MUCL 51663 & Surface pulverulent, relief umbonate & Pichia occidentalis & Pichia kudravzevii \\
DIV/08-182B & MUCL 51664 & Surface cerebriform & Saccharomyces cerevisiae & Saccharomyces cerevisiae \\
DIV/08-182C & MUCL 51665 & Surface smooth, relief umbonate & Saccharomyces cerevisiae & Saccharomyces cerevisiae \\
DIV/08-182D & MUCL 51666 & Small colonies, surface smooth & Saccharomyces cerevisiae & Saccharomyces cerevisiae \\
\hline
\end{tabular}

Table 2. Percentage of resistance of $\mathrm{CM}$ to $2.5,3$ and $4 \mathrm{pH}$ and to $0.03,0.05$ and 0.1 bile salts concentrations at time different.

\begin{tabular}{ccccccc}
\hline \multirow{2}{*}{ Time of incubation (h) } & \multicolumn{3}{c}{ Bile salts concentrations (\%) } & \multicolumn{3}{c}{$\mathrm{pH}$} \\
\cline { 2 - 7 } & 0.03 & 0.05 & 0.1 & 2.5 & 3 & - \\
\hline 1 & 99.4 & 15.2 & 5.9 & - & - & 7 \\
3 & 70.3 & 24.7 & 2.0 & 23.3 & 77.2 & 85.4 \\
\hline
\end{tabular}

The food transit time through the monogastric animals is about $90 \mathrm{~min}$ [34]. The tolerance at different $\mathrm{pH}$ and bile salt concentration obtained in this work indicate the possibility to explore the usefulness of this MC as probiotic in animal model. The MC should be tested to detect the possible production of adverse effect and be evaluated if this product could increase the health status of calves through of the stimulation of the immature newborn immune system preventing the diarrhea responsible for high mortality and morbidity in neonates [35-40].

\section{Acknowledgements}

Expert technical assistance was provided by Bioq. Gladys Martos (CERELA-Argentine), Dr. S. Van Trappen (BCCM/LMG, Belgium) and Dr. Heidi-Marie Daniel BCCM/MUCL, Belgium). Economic assistance was provided by Comisión de Investigaciones Científicas de la
Provincia de Buenos Aires, Agencia Nacional de Promoción Científica y Tecnológica and Universidad Nacional del Centro de la Provincia de Buenos Aires, Argentine.

\section{REFERENCES}

[1] M. R. Etzel, "Manufacture and Use of Dairy Protein Fractions,” Journal of Nutrition, Vol. 134, No. 6, 2004, pp. 996S-1002S.

[2] A. A Koutinas, I. Athanasiadis, A. Bekatorou, M. Iconomopoulou and G. Blekas, "Kefir Yeast Technology: ScaleUp in SCP Production Using Milk Whey,” Biotechnology and Bioenginering, Vol. 89, No. 7, 2005, pp. 788-796. doi:10.1002/bit.20394

[3] V. H. Holsinger, L. P. Posati and E. D. Devilbiss, "Whey Beverages: A Review,” Journal of Dairy Science, Vol. 57, No. 8, 1974, pp. 849-859. doi:10.3168/jds.S0022-0302(74)84976-3 
[4] M. Chartrain, L. Bhatnagar and J. G. Zeikus, "Microbial Ecophysiology of Whey Biomethanation: Comparison of Carbon Transformation Parameters, Species Composition, and Starter Culture Performance in Continuous Culture,” Applied Environmental Microbiology, Vol. 53, No. 5, 1987, pp. 1147-1156.

[5] R. Fuller, "Probiotics in Man and Animals, a Review," Journal of Applied Microbiology, Vol. 66, No. 5, 1989, pp. 365-378. doi:10.1111/j.1365-2672.1989.tb05105.x

[6] X. Chen, J. Xu, J. Shuai, J. Chen, Z. Zhang and W. Fang, "The S-Layer Proteins of Lactobacillus crispatus Strain ZJ001 Is Responsible for Competitive Exclusion against Escherichia coli O157: H7 and Salmonella typhimurium,” International Journal of Food Microbiology, Vol. 115, No. 3, 2007, pp. 307-312. doi:10.1016/j.ijfoodmicro.2006.11.007

[7] R. D. Rolfe, "The Role of Probiotic Cultures in the Control of Gastrointestinal Health," The Journal of Nutrition, Vol. 130, 2000, pp. 396S-402S.

[8] J. C. de Man, M. Rogosa and M. E. Sharpe, "A Medium for the Cultivation of Lactobacilli," Journal of Appied Bacteriology, Vol. 23, No. 1, 1960, pp. 130-135. doi:10.1111/j.1365-2672.1960.tb00188.x

[9] P. Raibaud, M. Caulet, J. V. Galpín and G. Mocquot, "Studies on the Bacterial Flora of the Alimentary Tract of Pigs, II Streptococci: Selective Enumeration of the Dominant Groups,” Journal of Applied Microbiology, Vol. 24, No. 3, 1961, pp. 285-306. doi:10.1111/j.1365-2672.1961.tb00262.x

[10] P. Vos, R. Hogers, M. Bleeker, M. Reijans, T. van de Lee, M. Hornes, A. Friters, J. Pot, J. Paleman, M. Kuiper and M. Zabeau, "AFLP: A New Technique for DNA Fingerprinting,” Nucleic Acids Research, Vol. 2, No. 21, 1995, pp. 4407-4414. doi:10.1093/nar/23.21.4407

[11] S. Gevers, G. Huys and J. Swings, "Applicability of Rep-PCR Fingerprinting for Differentiation of Lactobacillus Species,” FEMS Microbiology Letters, Vol. 205, No. 1, 2001, pp. 31-36. doi:10.1111/j.1574-6968.2001.tb10921.x

[12] K. Van Hoorde, T. Verstraete, P. Vandamme and G. Huys, "Diversity of Lactic Acid Bacteria in Two Flemish Artisan Raw Milk Gouda-Type Cheeses,” Food Microbiology, Vol. 25, No. 7, 2008, pp. 929-935. doi:10.1016/j.fm.2008.06.006

[13] V. Robert, P. Evrard and G. L. Hennebert, "BCCMTM/Allev 2.00 an Automated System for the Identification of Yeast,” Mycotaxon, Vol. 64, 1997, pp. 455- 463.

[14] N. J. W. Kreger-Van Rij, “Classification of Yeast,” In: A. H. Rose and J. S. Harrisonn, Eds., The Yeast, Academic Press Inc., London, 1987, pp. 5-61.

[15] J. P. Van der Walt and D. Yarrow, "Methods for de Isolation, Maintenance, Classification and Identification of Yeast,” In: N. J. W. Kreger-Van Rij, Ed., The Yeast, a Taxonomic Study, B. V. Elsevier Science Publishers, Amsterdam, 1984, pp. 45-104.

[16] C. P. Kurtzman and C. J. Robnett, "Identification and Phylogeny of Ascomycetous Yeasts from Analysis of Nuclear Large Subunit (26S) Ribosomal DNA Partial Sequences,” Antonie Van Leeuwenhoek, Vol. 73, No. 4,
1998, pp. 331-371. doi:10.1023/A:1001761008817

[17] J. A. Barnett, R. W. Payne and D. Yarrow, "Yeasts: Characteristics and Identification,” 3rd Edition, Cambridge University Press, Cambridge, 2000.

[18] T. J. White, T. Bruns, S. Lee and J. W. Taylor, "Conserved Primer Sequences for PCR Amplification and Sequencing from Nuclear Ribosomal RNA,” 1990. www.biology.duke.edu/fungi/mycolab/primers.htm

[19] T. A. Hall, "BioEdit: A User-Friendly Biological Sequence Alignment Editor and Analysis Program for Windows 95/98/NT,” Nucleic Acids Symposium Series, Vol. 41, No. 41, 1999, pp. 95-98.

[20] M. Groenewald, H. M. Daniel, V. Robert, G. A. Poot and M. T. Smith, "Polyphasic Re-Examination of Debaryomyces hansenii Strains and Reinstatement of D. hansenii, D. fabryi and D. subglobosus," Persoonia-Molecular Phylogeny and Evolution of Fungi, Vol. 21, No. 11, 2008, pp. 17-27. doi:10.3767/003158508X336576

[21] G. Vassart, M. Georges, R. Monsieur, H. Brogas, A. S. Lequarre and D. Christophe, “A Sequence in M13 Phage Detects Hypervariable Minisatellites in Human and Animal DNA,” Science, Vol. 235, No. 4789, 1987, pp. 683684. doi:10.1126/science.2880398

[22] G. Kociubinski, P. Pérez and G. de Antoni, "Screening of Bile Resistance and Bile of Precipitation in Lactic Acid Bacteria and Bifidobacteria,” Journal Food Protection, Vol. 62, No. 8, 1999, pp. 905-912.

[23] E. R. Famworth, "Kefir, a Complex Probiotic,” Food Science and Technology Bulletin: Functional Foods, Vol. 2, No. 1, 2005, pp. 1-17. doi:10.1616/1476-2137.13938

[24] K. B. Amor, E. E. Vaughan and W. M. de Vos, “Advanced Molecular Tools for the Identification of Lactic Acid Bacteria,” The Journal of Nutrition, Vol. 137, No. 3, 2007, pp. 741S-747S.

[25] C. Vael and K. Desager, "The Importance of Development of the Intestinal Microbiota in Infancy," Current Opinion of Pediatrics, Vol. 21, No. 6, 2009, pp. 794-800. doi:10.1097/MOP.0b013e328332351b

[26] M. Campieri and P. Gionchetti, "Probiotics in Inflammatory Bowel Disease: New Insight to Pathogenesis or a Possible Therapeutic Alternative?” Gastroenterology, Vol. 116 , No. 5, 1999, pp. 1246-1249. doi:10.1016/S0016-5085(99)70029-6

[27] I. Salinas, L. Abelli, F. Bertoni, S. Picchietti, A. Roque, D. Furones, A. Cuesta, J. Meseguer and M. A. Esteban, "Monospecies and Multispecies Probiotic Formulations Produce Different Systemic and Local Immunostimulatory Effects in the Gilthead Seabream (Sparus aurata L.)," Fish \& Shellfish Inmunology, Vol. 25, No. 1-2, 2008, pp. 114123. doi:10.1016/j.fsi.2008.03.011

[28] M. Collado, J. Meriluoto and S. Salminen, "Measurement of Aggregation Properties between Probiotics and Pathogens: In Vitro Evaluation of Different Methods,” Journal of Microbiological Methods, Vol. 71, No. 1, 2007, pp. 71-74. doi:10.1016/j.mimet.2007.07.005

[29] H. M. Timmerman, L. E. Niers, B. U. Ridwan, C. J. Koning, L. Mulder, L. M. Akkermans, F. M. Rombouts and G. T. Rijkers, "Design of a Multispecies Probiotic Mixture to Prevent Infectious Complications in Critically 
Ill Patients,” Clinical Nutrition, Vol. 26, No. 4, 2007, pp. 450-459. doi:10.1016/j.clnu.2007.04.008

[30] T. Hosoi, A. Ametani, K. Kiuchi and S. Kaminogawa, "Improved Growth and Viability of Lactobacilii in the Presence of Bacillus subtilis, Catalase, or Subtilisin," Canadian Journal of Microbiology, Vol. 46, No. 10, 2000, pp. 892-897.

[31] A. C. Ouwehand, E. Isolauri, P. V. Kirjavainen, S. Tö Ikkö and S. J. Salminen, "The Mucus Binding of BifidoBacterium Lactis Bb12 Is Enhanced in the Presence of Lactobacillus GG and Lact. Delbrüekii Subsp. Bulgaricus," Letters in Applied Microbiology, Vol. 30, No. 1, 2000, pp. 10-13. doi:10.1046/j.1472-765x.2000.00590.x

[32] H. M. Timmerman, C. J. Koning, L. Mulder, F. M. Romboust and A. C. Beynen, "Monostrain, Multistrain and Multispecies Probiotics: A Comparison of Functionality and Efficacy," International Journal of Food Microbiology, Vol. 96, No. 219, 2004, pp. 219-233. doi:10.1016/j.ijfoodmicro.2004.05.012

[33] I. Salinas, A. Cuesta, M. A. Esteban and J. Meseguer, "Dietary Administration of Lactobacillus delbrüeckii and Bacillus subtilis, Single or Combined, on Gilthead Seabream Cellular Innate Immune Responses," Fish \& Shellfish Inmunology, Vol. 19, No. 1, 2005, pp. 67-77. doi:10.1016/j.fsi.2004.11.007

[34] E. Renner, "Cultured Dairy Products in Human Nutrition,” Bulletin of the International Dairy Federation, Vol. 225, 1991, pp. 2-24.

[35] E. L. Morrell, D. P. Moore, A. C. Odeón, M. A. Poso, E. Odriozola, G. Cantón, F. Paolicchi, F. Malena, M. R. Leunda, C. Marsella and C. M. Campero, "Retrospective
Study of Bovine Neonatal Mortality: Cases Reported from INTA Balcarce, Argentina,” Revista Argentina de Microbiología, Vol. 40, No. 3, 2008, pp. 151-157.

[36] L. S. Frizzo, E. Bertozzi, L. P. Soto, M. V. Zbrun, G. J. Sequeira, R. Dalla Santina and R. Rodriguez Armestro, "The Effect of Supplementation with Three Lactic Acid Bacteria from Bovine Origin on Growth Performance and Health Status of Group Calves,” Journal of Animal and Veterinary Advances, Vol. 7, No. 4, 2008, pp. 400-408.

[37] M. R. Mokhber-Dezfouli, P. Tajik, M. Bolourchi and H. Mahmoudzadeh, "Effects of Probiotics Supplementation in Daily Milk Intake of Newborn Calves on Body Weight Gain, Body Height, Diarrhea Occurrence and Health Condition,” Journal of Biological Science, Vol. 10, No. 18, 2007, pp. 3136-3140.

[38] H. M. Timmerman, L. Mulder, H. Everts, D. C. van Espen, E. van der Wal, G. Klaassen, S. M. Rouwers, R. Hartemink, F. M. Rombousts and A. C. Beynen, "Health and Growth of Veal Calves Fed Milk Replacers with or without Probiotics,” Journal of Dairy Science, Vol. 88, No. 6, 2005, pp. 2154-2165. doi:10.3168/jds.S0022-0302(05)72891-5

[39] Q. Shu and H. S. Gill, "Immune Protection Mediated by the Probiotic Lactobacillus Rhamnosus HN001 against Escherichia coli O157: H7 Infection in Mice," FEMS Immonulogy and Medical Microbiology, Vol. 34, No. 1, 2002, pp. 59-64.

[40] E. Isolauri, Y. Sütas, P. Kankaanpää, H. Arvilommi and S. Salminen, "Probiotics: Effects on Immunity," American Journal of Clinical Nutrition, Vol. 73, No. 2, 2001, pp. 444S-450S. 